This article was downloaded by: [National Taiwan University]

On: 7 October 2009

Access details: Access Details: [subscription number 908165529]

Publisher Psychology Press

Informa Ltd Registered in England and Wales Registered Number: 1072954 Registered office: Mortimer House, 37-41 Mortimer Street, London W1T 3JH, UK

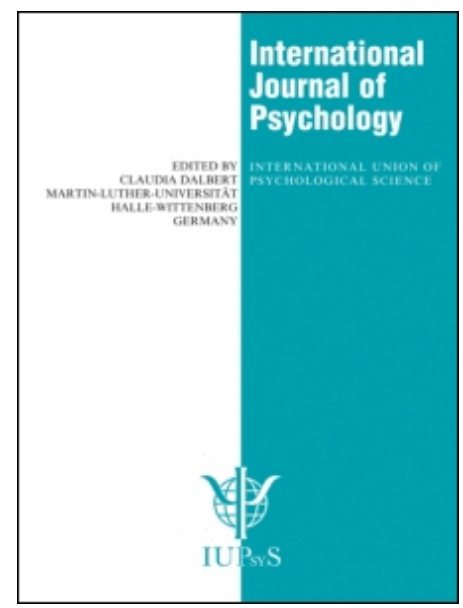

\title{
International Journal of Psychology
}

Publication details, including instructions for authors and subscription information:

http://www.informaworld.com/smpp/title content=t713659663

\section{Relations among self-certainty, sense of control and quality of life}

Chia-huei Wu a; Grace Yao a

a National Taiwan University, Taipei, Taiwan

First Published on: 28 August 2007

To cite this Article Wu, Chia-huei and Yao, Grace(2007)'Relations among self-certainty, sense of control and quality of life',International Journal of Psychology, 42:5,342 - 352

To link to this Article: DOI: $10.1080 / 00207590701264831$

URL: http://dx.doi.org/10.1080/00207590701264831

\section{PLEASE SCROLL DOWN FOR ARTICLE}

\footnotetext{
Full terms and conditions of use: http://www.informaworld.com/terms-and-conditions-of-access.pdf

This article may be used for research, teaching and private study purposes. Any substantial or systematic reproduction, re-distribution, re-selling, loan or sub-licensing, systematic supply or distribution in any form to anyone is expressly forbidden.

The publisher does not give any warranty express or implied or make any representation that the contents will be complete or accurate or up to date. The accuracy of any instructions, formulae and drug doses should be independently verified with primary sources. The publisher shall not be liable for any loss, actions, claims, proceedings, demand or costs or damages whatsoever or howsoever caused arising directly or indirectly in connection with or arising out of the use of this material.
} 


\title{
Relations among self-certainty, sense of control and quality of life
}

\author{
Chia-huei Wu and Grace Yao \\ National Taiwan University, Taipei, Taiwan
}

\begin{abstract}
$T$ his article investigates the mediation effect of the sense of control on the relationship between self-certainty and quality of life (QOL). In the first study, 101 students at National Taiwan University (NTU) completed a self-certainty rating scale with respect to interpersonal traits of the general self and three role-specific selves (son/daughter, sibling, and friend). They also filled out the WHOQOL-BREF (World Health Organization Quality of Life questionnaire - brief version) Taiwan version to assess QOL. A two-factor confirmatory factor analysis revealed that self-certainty on interpersonal traits has a positive relationship with QOL. In the second study, 121 NTU students completed a self-certainty rating scale with respect to personality traits of the general self and two role-specific selves (son/daughter and friend), a control scale measuring sense of control, and the WHOQOL-BREF Taiwan version assessing QOL. A two-factor confirmatory factor analysis revealed that selfcertainty on personality traits has a positive relationship with QOL. In addition, a structural equation model revealed that the sense of self-control mediated the positive relation between self-certainty and QOL. The findings showed that people with higher self-certainty had a higher sense of control and, hence, led a better life. The results also showed that the positive relationship between self-certainty and QOL was stronger when self-certainty was assessed with interpersonal traits than with personality traits. Implications of this study for self research and adjustment are discussed.
\end{abstract}

\begin{abstract}
$C$ et article examine l'effet de médiation du sens de contrôle sur la relation entre la certitude et soi la qualité de vie (QdV). Dans la première étude, 101 étudiants de l'Université Nationale de Taiwan (NTU) ont complété une échelle de mesure de la certitude de soi en lien avec les traits interpersonnels du moi général et de trois rôles spécifiques du moi (fils/fille, fratrie et ami(e)). Les participants ont aussi complété le WHOQOL-version taïwanaise abrégée pour évaluer la qualité de vie (QdV) (Instrument d'évaluation de la qualité de vie développé par l'Oganisation Mondiale de la Santé). Une analyse factorielle confirmatoire à deux facteurs a indiqué que la certitude de soi par rapport aux traits interpersonnels a une relation positive avec la QdV. Dans la deuxième étude, 121 étudiants de la NTU ont complété un questionnaire mesurant la certitude de soi quant aux traits de personnalité du moi général et de deux rôles spécifiques du moi (fils/fille et amie(e)), une échelle mesurant le sens de contrôle ainsi que le WHOQOL-version taïwanaise abrégée évaluant la QdV. Une analyse factorielle confirmatoire à deux facteurs a montré que la certitude de soi quant aux traits de personnalité a une relation positive avec la QdV. En plus, un modèle d'équation structurelle a indiqué que le sens de contrôle de soi a été un médiateur de la relation positive entre la certitude de soi et la QdV. Les résultats ont montré que les gens qui ont une certitude de soi plus élevée avaient un sens de contrôle plus élevé et menaient ainsi une meilleure vie. Les résultats ont aussi indiqué que la relation positive entre la certitude de soi et la QdV était plus forte quand la certitude de soi était évaluée avec des traits interpersonnels plutôt qu'avec des traits de personnalité. Les implications de cette étude pour la recherche sur le moi et pour l'ajustement sont discutées.
\end{abstract}

$F$ ste artículo trata del efecto de mediación del sentido de control en la relación entre auto-certeza y la calidad rellenado la escala de auto-certeza, refiriéndose a los rasgos interpersonales del yo general y tres yo específicos según el rol (hijo/hija, hermano/hermana, amigo/amiga). También rellenaron WHOQOL-BREF (Cuestionario de la Calidad de Vida de la Organización Mundial de la Salud-versión corta) versión para Taiwán para evaluar QOL. El análisis factorial confirmatorio de dos factores reveló que la auto-certeza tiene relación positiva con

Correspondence should be addressed to Yao, Grace, Department of Psychology, National Taiwan University, 1, Sec. 4, Roosevelt RD, Taipei, Taiwan (E-mail: kaiping@ntu.edu.tw).

This study was supported by National Science Council (NSC 94-2413-H-002-018) and the National Health Research Institute (NHRI-EX94-9204PP). 
QOL en caso de rasgos interpersonales. En el segundo estudio 121 estudiantes de NTU han rellenado la escala de auto-certeza refiriéndose a los rasgos de personalidad del yo general y de los dos yo específicos según el rol (hijo/ hija, amigo/amiga), una escala de control la cual mide el sentido de control y WHOQOL-BREF versión para Taiwán la cual mide QOL. Un análisis factorial confirmatorio de dos factores reveló que la auto-certeza en los rasgos de personalidad tiene relación positiva con QOL. Adicionalmente, el modelo de ecuaciones estructurales reveló que el sentido de auto-control ha mediado la relación positiva entre la auto-certeza y QOL. Los resultados demuestran que las personas con la auto-certeza más alta tenían más alto el sentido de control y por eso sus vidas eran mejores. También se demuestra que la relación positiva entre auto-certeza y QOL fue más fuerte cuando la auto-certeza se evaluaba con rasgos interpersonales que rasgos de personalidad. Se discute las implicaciones de estos estudios en auto investigación y ajuste.

Self-certainty is regarded as an important factor in individual well-being. Previous studies have indicated that self-certainty is positively related to selfesteem, purpose in life, sense of coherence, affect balance, general contentment, social self-esteem, and positive affect (Baumgardner, 1990; Bigler, Neimeyer, \& Brown, 2001; Campbell, 1990; Campbell, Assanand, \& Di Paula, 2003; Campbell et al., 1996), and negatively related to neuroticism, depression, and anxiety (Bigler et al., 2001; Campbell et al., 1996, 2003). People with greater self-certainty are better adjusted and lead a better life. But why does self-certainty correspond to positive adjustment?

One possible reason for the positive relationship between self-certainty and adjustment is provided by self-regulation theory (Carver \& Scheier, 1998), according to which humans are regarded as complex goal-directed systems that self-regulate actions with respect to those goals. In the selfregulation process, individuals guide their actions with their goals and use feedback to modify their actions, or even their goals. Accordingly, selfcertainty would clearly contribute to setting goals, guiding action, and reconciling conflicting feedback. People with high self-certainty know what characteristics they possess, and they use this selfknowledge to attune their criteria or take appropriate actions in various situations, which then contribute to the better adjustment.

Setterlund and Niedenthal's study (1993) supported this theory with the finding that people with higher self-certainty tend to use a prototype matching strategy (a decision-making strategy in which one's self-concept guides one's choices) in a choice task. Their results suggest that people with higher self-certainty choose more appropriate situations and avoid risky situations that may threaten self-esteem.

This characteristic may also contribute to selfconfidence and positive self-affect. Baumgardner (1990) demonstrated that providing individuals with certain information about their self could induce an increase in positive self-affect and egotism, which indicates that self-certainty can generate positive affect and self-confidence. Baumgardner concluded that those with higher self-certainty are more confident in handling their feelings, thoughts, and behaviours in different situations, which in turn contributes to a sense of control over their lives.

\begin{abstract}
Self-certainty, or perceptions of self-certainty, may very well contribute to a sense of control in that the individual who has a certain identity should have a concomitant perception that he or she has control over future outcomes. As noted at the outset, the self-certain individual should believe that he can maximize his outcomes because he thinks he knows what he can or cannot do" (Baumgardner, 1990, p. 106).
\end{abstract}

Indeed, Trope and Ben-Yair's study (1982) demonstrated that people with high self-certainty choose circumstances in which they are allowed to exhibit competence and they avoid demanding circumstances that might cause failure, showing that certainty about oneself can enhance a sense of control over future situations.

Because many studies have linked a sense of control to greater life satisfaction (e.g., Lachman \& Weaver, 1998; Wardle et al., 2004) and better health and functional status (e.g., Lachman \& Weaver, 1998; Langer \& Rodin, 1976; Rodin, 1986; Rodin \& Langer, 1977; Rodin, Timko, \& Harris, 1985; Schulz, 1976; Schulz \& Hanusa, 1978; Seeman \& Seeman, 1983; Wardle et al., 2004), it can be expected that people with higher self-certainty would have a stronger sense of control and hence lead a better life. We hypothesize that the positive relationship between selfcertainty and adjustment is mediated by the sense of control. Two studies were conducted to test this hypothesis. In the first study, the relationship between self-certainty and adjustment was examined. In the second study, the mediation effect of the sense of control on the relationship between self-certainty and adjustment was examined. 


\section{STUDY 1}

The aim of this study is to examine the relationship between self-certainty and adjustment. Although a positive relationship has been shown in previous studies, we decided to examine the relation again using a different research design that includes the social self in addition to a general self, because the self is shaped by social interactions (e.g., Bowlby, 1969; Cooley, 1902; Mead, 1934; Sullivan, 1953). We measured self-certainty by referencing Baumgardner's (1990) and Campbell's (1990) method, which assumes that self-certainty is reflected in the level of confidence in self-descriptions. We assessed it in relation to the general self and also in relation to three different roles: son/ daughter, sibling, and friend. This research design provided an opportunity to evaluate whether context-specific self-certainty would better predict adjustment than general self-certainty.

The World Health Organization Quality of Life questionnaire Taiwan brief version (WHOQOLBREF Taiwan version; Yao, Chung, Yu, \& Wang, 2002) was chosen to assess individuals' adjustment because it measures their quality of life (QOL) in four domains (physical, psychological, social relations, and environmental) that define adjustment in the context of a substantial background with various life experiences, instead of as an abstract construct. The relation between self-certainty and QOL was examined with a two-factor CFA (confirmatory factor analysis) model, in which four self-certainty scores were used to indicate the self-certainty factor, while the quality of the four life domains were used to indicate the QOL factor.

\section{Method}

\section{Participants and procedure}

Forty-four male and 57 female undergraduates (mean age $=19.6$ years, $S D=1.7$ ) at National Taiwan University participated in the study. They were given an extra credit in their introductory psychology course for participation.

\section{Instruments}

Self-certainty rating scale. A total of 16 adjective traits were selected from Wiggins' (1979) interpersonal domains. Participants indicated how appropriately each trait described them on a 7point Likert scale anchored by strongly disagree (1) and strongly agree (7). They were then asked to rate how certain they felt about their ratings on a 7-point Likert scale anchored by not at all certain
(1) to very certain (7). An example of an item for the general rating is: "How well does 'warm' describe you?", and "How certain are you?" Selfcertainty was calculated by averaging the confidence ratings for the 16 traits (Cronbach's alpha is .92 for the 16 certainty ratings).

In addition to rating themselves in a general sense, participants also rated themselves on the same traits in the context of three different social roles: son/daughter, sibling, and friend. Selfcertainty for each of the three social selves was calculated by averaging the confidence ratings of the 16 traits for each role (Cronbach's alpha ranged from .94 to .95 for the 16 certainty ratings for each role). In all cases, a higher average score on the certainty ratings represented higher selfcertainty.

WHOQOL-BREF Taiwan version. The WHOQOL-BREF Taiwan version was developed from the WHOQOL-BREF. It contains 24 facets within four domains related to quality of life (physical health, psychological health, social relationships, and environmental health) as well as one facet measuring overall quality of life and general health. It has a total of 28 items, composed of 26 standard WHOQOL-BREF items and 2 (culturally relevant) national items. Sample items from the four domains are "Do you have enough energy for everyday life?" (physical health; 7 items), "How much do you enjoy life?" (psychological domain; 6 items), "How satisfied are you with your personal relationships?" (social relationships; 3 items), and "How healthy is your physical environment?" (environmental health; 8 items). The two items for overall quality of life and general health are "How would you rate your quality of life?" and "How satisfied are you with your health?" The two national items are "Do you feel respected by others?" and "Are you usually able to get the things you like to eat?", which are in the social relationships and the environmental domains respectively. Each item has to be answered on a 5-point Likert scale anchored by one of four kinds of scale descriptors, that is, not at all (1) to completely (5) for capacity questions, never (1) to always (5) for frequency questions, not at all (1) to extremely (5) for intensity questions, and very dissatisfied (1) to very satisfied (5) for evaluation questions.

In Yao et al.'s (2002) study, exploratory and confirmatory factor analyses of the WHOQOLBREF Taiwan version revealed a four-factor model (physical, psychological, social, and environmental factors). The internal consistency (Cronbach's alpha) coefficients ranged from .70 
to .77 for the four domains $(.73$ to .83 in this study). The test-retest reliability coefficients with a 2- to 4 -week interval ranged from .41 to .79 at the item level and .76 to .80 at the domain level (all $p s<.01)$. Item-domain correlations were in the range of .53 to .78 and inter-domain correlations were in the range of .51 to .64 (all $p s<.01$ ). In this study, the four domain scores were computed with the standard scoring algorithms of the WHOQOLBREF Taiwan version. That is, after computing the average score of items in each domain, the average score was multiplied by four to make the score range from 4 to 20 . A higher score represented a higher quality of life.

\section{Data analysis}

Descriptive and correlation analyses were performed first to investigate the relationships among the variables. Then, structural equation modelling was conducted to examine the hypothetical model described earlier using LISREL 8.0 (Joreskog \& Sorbom, 1993). The maximum likelihood method was used for model estimation because the observed data did not depart much from a normal distribution. Four fit indices were used in conjunction with Chi-square tests to evaluate the model. Two incremental fit indices, the nonnormed fit index (NNFI) and the comparative fit index (CFI), were chosen. A value of NNFI and CFI exceeding .95 indicates a good fit, while a value between .90 and .95 represents an adequate fit (Bentler, 1990; Hoyle, 1995). More recently, $\mathrm{Hu}$ and Bentler (1999) suggested a more stringent cutoff of .95 or above on the NNFI and CFI. In addition, two absolute fit indices, the standardized root mean squared residual (SRMR) and the root mean squared error of approximation (RMSEA), were also used. RMSEA should be at or below .05 for a well-fitting model, and at or below .08 for a reasonably fitting model (Browne \& Cudeck,
1993). Hu and Bentler suggested a cutoff value of .06 for a well-fitting model. For SRMR, Hu and Bentler suggested that it should be at .08 or less for a good fit. In addition, they also recommended using a cutoff value close to .95 for CFI in combination with a cutoff value close to .09 for SRMR to evaluate model fit $(\mathrm{CFI} \geqslant .95$; SRMR $\leqslant .09$ ). These rules for fit indices were considered when making a general conclusion in model evaluation. However, we did not totally rely on the values of fit indices; the significance of specific estimates (i.e., factor loadings and path loadings) and theoretical interpretation were also considered when making the final decision.

\section{Results and discussion}

The means, standard deviations, and correlations among all variables are presented in Table 1 . Correlation analyses revealed that the four certainty scores were highly correlated. The correlation coefficients ranged from .78 to .88 (all $p s<.01$ ). In addition, the correlations among the four QOL scores were all positively significant, ranging from .45 to .71 (all $p s<.01$ ). Finally, the four certainty scores generally had positive correlations with the four QOL scores. The correlation coefficients ranged from .18 to $.38(p s<.01)$.

In order to summarize the relation between selfcertainty and QOL and partial out the measurement error of each variable, a confirmatory factor analysis (CFA) with a two-factor model (selfcertainty and QOL factors) was conducted. In this model, the four self-certainty variables were influenced by the certainty factor, the four QOL domains were influenced by the QOL factor, and the unique variances of each variable were uncorrelated. In addition, the factor variances were set as 1 , and the two factors were set to be correlated. This model was an over-identification model with 19 degree of freedom (36 data points

TABLE 1

Descriptive statistics of all variables in Study $1(N=101)$

\begin{tabular}{|c|c|c|c|c|c|c|c|c|c|}
\hline & $M$ & $S D$ & 1 & 2 & 3 & 4 & 5 & 6 & 7 \\
\hline 1.Certainty on the general self & 5.57 & 0.71 & - & & & & & & \\
\hline 2.Certainty on the son/daughter role-self & 5.71 & 0.76 & $.79 * *$ & - & & & & & \\
\hline 3.Certainty on the sibling role-self & 5.75 & 0.75 & $.80 * *$ & $.87 * *$ & - & & & & \\
\hline 4.Certainty on the friend role-self & 5.71 & 0.79 & $.78^{* *}$ & $.78^{* *}$ & $.88^{* *}$ & - & & & \\
\hline 5.QOL-Phy & 13.93 & 2.26 & $.25^{*}$ & $.23^{*}$ & $.29 * *$ & $.23^{*}$ & - & & \\
\hline 6.QOL-Psy & 13.29 & 2.66 & $.35^{* *}$ & $.30^{* *}$ & $.38^{* *}$ & $.35^{* *}$ & $.70^{* *}$ & - & \\
\hline 7.QOL-Soc & 13.32 & 2.56 & $.31^{* *}$ & $.21^{*}$ & $.37^{* *}$ & $.33^{* *}$ & $.55^{* *}$ & $.71^{* *}$ & - \\
\hline 8.QOL-Env & 13.63 & 1.99 & $.23^{*}$ & .18 & $.35^{* *}$ & $.32 * *$ & $.54^{* *}$ & $.54^{* *}$ & $.45^{* *}$ \\
\hline
\end{tabular}

QOL-Phy = physical health of quality of life; QOL-Psy = psychological domain of quality of life; QOL-Soc = social relationships of quality of life; QOL-Env = environment domain of quality of life. ${ }^{*} p<.05 ; * *<<.01$. 
with 17 parameters). The CFA result is presented in Figure 1. All estimates in the model were significant, and except for Chi-square test, $\chi^{2}(19)=33.76$, $p<.05$, fit indices suggested that this two-factor model was acceptable $(\mathrm{NNFI}=.97$; CFI $=.98$; RMSEA $=.08 ;$ SRMR $=.039$ ). Thus, the model was retained after the overall information from the Chi-square test, various fit indices, and parameter estimates were brought into consideration. The correlation between self-certainty and QOL was $.43(p<.01)$, supporting the hypothesis that selfcertainty and QOL are positively correlated.

Because the 16 traits used in assessing selfcertainty were all selected from Wiggins' (1979) interpersonal domains, we cannot be sure whether the positive relationship between self-certainty and QOL would still exist if personality traits were used to evaluate self-certainty. Moreover, we hypothesized that people with high self-certainty would have a stronger sense of control over their life situation, which results in a better life. This hypothesis was not addressed in the first study. In the following study, these two considerations are taken into account.

\section{STUDY 2}

The purpose of this study is to examine (1) whether the positive relationship between selfcertainty and QOL still exists if personality traits are used to evaluate self-certainty, and (2) the mediation effect of the sense of control on the

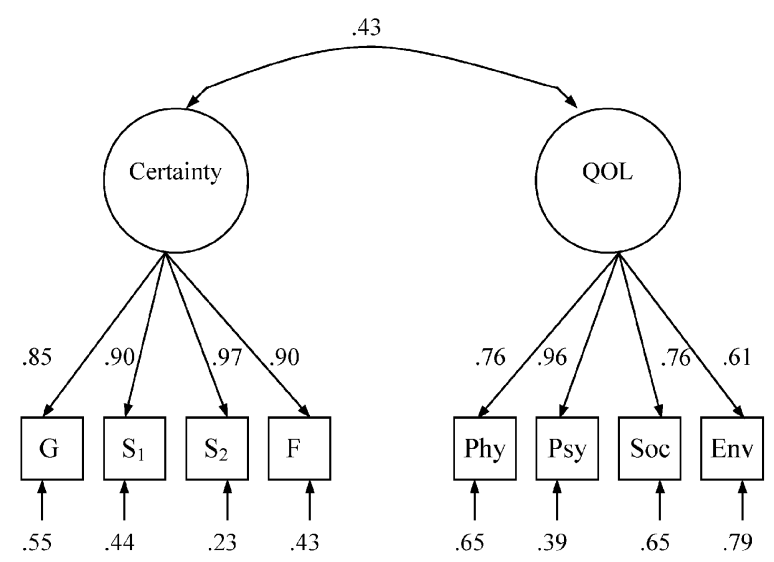

Figure 1. Complete standardized estimates of two-factor CFA model (all estimates were significant at $p s<.01$ ). $\mathrm{G}$ $=$ certainty on general self; $S_{1}=$ certainty on the son/ daughter role-self; $\mathrm{S}_{2}=$ certainty on the sibling roleself; $\mathrm{F}=$ certainty on the friend role-self; Phy = physical health of quality of life; Psy = psychological domain of quality of life; Soc $=$ social relationships of quality of life; Env = environment domain of quality of life. relationship between self-certainty and QOL. For this study, self-certainty rating scales were constructed with 15 personality traits selected from the Big-Five model ( 3 traits per dimension). QOL was again assessed with the WHOQOL-BREF Taiwan version, and the sense of self-control was evaluated with the Spheres of Control Scalerevised version (SOC-R; Paulhus \& Van Selst, 1990). All examinations were conducted using structural equation models.

\section{Method}

\section{Participants and procedure}

Thirty-four male and 87 female undergraduates (mean age $=20.1$ years, $S D=1.72$ ) at the National Taiwan University (NTU) participated in exchange for extra credit in their introductory psychology course. It took an average of 30 minutes to complete the measures.

Self-certainty rating scale. In this study, 15 adjective traits selected from the Big-Five model (3 traits per dimension) were used to assess individuals' self-certainty. Participants were asked to indicate how appropriately these traits described them on a 7-point Likert scale anchored by strongly disagree (1) and strongly agree (7). Participants were then asked to rate how certain they felt about their ratings on a 7-point Likert scale anchored by not at all certain (1) and very certain (7) for each trait. In addition to making a general rating, participants also rated themselves on the same traits in two different social roles, including son/daughter and friend. The role of sibling was excluded to reduce participants' burden. The Cronbach's alphas for the three selfcertainty scores were $.86, .91$, and .93 , respectively.

WHOQOL-BREF Taiwan version. The WHOQOL-BREF Taiwan version was also administered in this study. The internal consistency (Cronbach's alpha) coefficients ranged from .61 to .82 for the four domains.

The Spheres of Control Scale-revised version (SOC-R). The SOC-R, refined by Paulhus and Van Selst (1990), differentiates the concept of locus of control into three major spheres of life: personal control, interpersonal control, and socialpolitical control. There are 10 items in each subscale. Participants responded on a 7-point Likert scale ranging from strongly disagree (1) to strongly agree (7). In this study, only the personal control subscale was administered. Spittal, Siegert, 
McClure, and Walkey (2001) suggested that the factor structure of this subscale is not sufficiently clear. In their study (see their Table 1), only five items $(1,2,4,5,8)$ showed higher loadings (above .40) on the same factor. For the current sample, results of exploratory factor analysis with the principal axis method showed that there were two factors underlying the subscale. The first factor could be termed a Positive Wording factor. Its five items describe the sense of control using positive wording. These five items are the same five as in Spittal et al.'s study. The other factor could be termed the Negative Wording factor. Its four items $(6,7,9,10)$ describe the sense of control using negative wording. Item 3 had the same loading on both factors. The factor correlation was -.20, suggesting that positively and negatively worded items might have different meanings, as the two factors underlying the scale were not strongly correlated. Since items with positive wording are typical control statements across measurements on the sense of control (see Lefcourt, 1991), only the positively worded items were used to index the sense of control. They are: (Item 1) I can usually achieve what I want if I work hard for it; (Item 2) Once I make plans, I am almost certain to make them work; (Item 4) I can learn almost anything if I set my mind to it; (Item 5) My major accomplishments are entirely due to my hard work and ability; and (Item 8) Almost anything is possible for me if I really want it. The mean of these five items represented the level of personal control. The Cronbach's alpha of the five items was .85 .

\section{Results}

The means, standard deviations, and correlations among all variables aere presented in Table 2. Correlation analyses revealed that the three certainty scores were highly correlated $(r=.63$ to .85 , all $p s<.01$ ). In addition, the correlations among the four QOL scores were positively significant, ranging from .34 to .67 (all $p s<.01$ ). The three certainty scores generally had positive correlations with physical and psychological QOL $(r=.11$ to $.25, p \mathrm{~s}<.05)$. However, the three certainty scores did not have significant correlations with the social relationship and environmental domains of QOL. Personal control had a positive correlation with all certainty scores and QOL scores. The correlation coefficients ranged from .25 to .48 (all $p \mathrm{~s}<.01)$.

In order to summarize the relation between selfcertainty assessed by personality traits and QOL, a two-factor CFA model (self-certainty and QOL factors) was conducted. The specification of the model was similar to the model used in Study 1 . All estimates in the model were significant, and except for the Chi-square test, $\chi^{2}(13)=26.43$, $p<.05$, the fit indices suggested that this two-factor model was retainable $(\mathrm{NNFI}=.95$; $\mathrm{CFI}=.97$; RMSEA $=.089$; SRMR $=.060$ ). Thus, the model was accepted after considering the Chi-square test, the various fit indices, and parameter estimates. The correlation between self-certainty and QOL was .25 $(p<.01)$, revealing that self-certainty in personality traits also had a positive relationship with QOL. However, the strength is of the relationship is weaker than in the Study 1.

Further, in order to test the mediation effect of personal control on the relationship between selfcertainty and QOL, a structural equation model was specified. In this model, the three self-certainty variables were influenced by the certainty factor, the four QOL domains were influenced by the QOL factor, the five items for personal control were influenced by the control factor, and the unique variances of each variable were uncorrelated. All factor variances were set to 1 . In

TABLE 2

Descriptive statistics of all variables in Study $2(N=121)$

\begin{tabular}{|c|c|c|c|c|c|c|c|c|c|}
\hline & $M$ & $S D$ & 1 & 2 & 3 & 4 & 5 & 6 & 7 \\
\hline 1.Certainty on the general self & 5.59 & 0.65 & - & & & & & & \\
\hline 2.Certainty on the son/daughter role-self & 5.70 & 0.72 & $.63^{* *}$ & - & & & & & \\
\hline 3.Certainty on the friend role-self & 5.67 & 0.79 & $.63^{* *}$ & $.85^{* *}$ & - & & & & \\
\hline 4.Sense of control & 4.75 & 1.05 & $.38^{* *}$ & $.30 * *$ & $.26^{* *}$ & - & & & \\
\hline 5.QOL-Phy & 13.46 & 1.99 & $.24^{* *}$ & $.28 * *$ & $.21^{*}$ & $.43^{* *}$ & - & & \\
\hline 6.QOL-Psy & 12.55 & 2.57 & $.23^{*}$ & $.21 *$ & .11 & $.48^{* *}$ & $.67^{* *}$ & - & \\
\hline 7.QOL-Soc & 13.50 & 2.32 & .07 & .01 & -.03 & $.25^{* *}$ & $.34 * *$ & $.53 * *$ & - \\
\hline 8.QOL-Env & 13.55 & 1.98 & .16 & .17 & .16 & $.27^{* *}$ & $.58^{* *}$ & $.52^{* *}$ & $.47 * *$ \\
\hline
\end{tabular}

QOL-Phy = physical health of quality of life; QOL-Psy = psychological domain of quality of life; QOL-Soc = social relationships of quality of life; QOL-Env = environment domain of quality of life. ${ }^{*} p<.05 ; * *<.01$. 
addition, the certainty factor had a direct effect on the control factor, which had a direct effect on the QOL factor. There was no direct effect of the certainty factor on the QOL factor. This model was an over-identification model with 52 degrees of freedom (78 data points with 26 parameters). The result is presented in Figure 2. All estimates in the model were significant, and except for the Chisquare test, $\chi^{2}(52)=75.04, p<.05$, the fit indices suggested that this model was retainable $(\mathrm{NNFI}=$ .97 CFI $=.98$; RMSEA $=.057$; SRMR $=.068)$. The indirect effect of the certainty factor on the QOL factor through the personal control factor was significant (standardized indirect effect $=.20$, $p<.01$ ). When the direct effect of the certainty factor on the QOL factor was added, this direct effect was not significant. Thus, all the findings revealed that there is a positive relationship between self-certainty and QOL, and that this relationship is mediated by personal control.

\section{GENERAL DISCUSSION}

According to the results of both studies, it is clear that self-certainty has a positive relationship with QOL whether self-certainty is assessed with interpersonal traits (Study 1) or personality traits (Study 2). The mediation analysis indicated that the positive relation between self-certainty and QOL is mediated by a sense of personal control. All these findings support the hypothesis that individuals with high self-certainty have a higher sense of personal control and lead a better life. In addition to this general conclusion, several specific results are worth discussing.

\section{Certainty on interpersonal traits and personality traits}

The positive relationship between self-certainty and QOL was stronger when self-certainty was assessed with interpersonal traits than with personality traits. For example, self-certainty as assessed by interpersonal traits was significant for all QOL scores; self-certainty as assessed by personality traits was only significant with the physical and psychological QOL scores. Theoretically one might not expect to find a positive relationship between self-certainty and all of the QOL domain scores, especially the environmental domain. However, past studies on the WHOQOL-BREF (and this study) have found that the four domains are highly correlated and share a common latent factor (e.g., Skevington, Lotfy, \& O'Connell's study, 2004; Yao et al., 2002). Thus, we interpret the difference between Studies 1 and 2 as a difference in the strength of the relationship between self-certainty and QOL. Indeed, results from the two-factor CFA model showed that the correlation between the selfcertainty factor with interpersonal traits and the QOL factor was .43, which is higher than the correlation between the self-certainty factor with personality traits and the QOL factor $(r=.25)$.

Accordingly, it may be speculated that certainty with interpersonal traits is more beneficial than certainty with personality traits. This finding may reflect the interpersonal context effect in shaping self-concept. The interpersonal context effect on self-concept is consistent with classic theories on self-concept development (e.g., Bowlby, 1969; Cooley, 1902; Mead, 1934; Sullivan, 1953), in

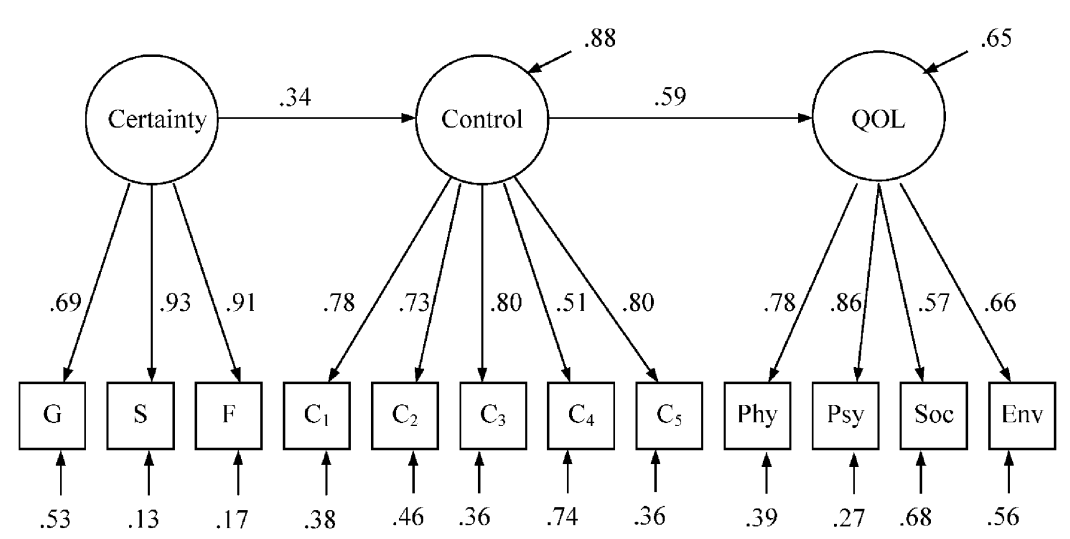

Figure 2. Complete standardized estimates of the mediation model (all estimates were significant at $p \mathrm{~s}<.01$ ). $\mathrm{G}=$ certainty on general self; $\mathrm{S}=$ certainty on the son/daughter role-self; $\mathrm{F}=$ certainty on the friend role-self; $\mathrm{C}_{1}$ to $\mathrm{C}_{5}=$ five items in control scale; Phy = physical health of quality of life; Psy = psychological domain of quality of life; $\mathrm{Soc}=$ social relationships of quality of life; Env $=$ environment domain of quality of life. 
which social interactions are regarded as an important basis for developing the self-concept. From this perspective, interpersonal traits are better than personality traits for assessing the nature of a person's certainty of self-concept, because interpersonal traits can incorporate the social effects of the interpersonal context. In addition, adding the relationship-specific context (with the different social roles) to assess selfcertainty also enhanced the beneficial effect. Participants relied on the specific context to retrieve their performance in that situation, and thus were able to feel more confidence in their ratings on these traits. Indeed, the two-factor CFA results in both studies revealed that loadings for the certainty of the social role-selves were higher than those of the general self.

This finding can also be explained from the viewpoint of cultural psychology. Indigenous Chinese psychologists (e.g., Hwang, 2000; K. S. Yang, 2004; C. H. Yang \& Kao, 1991) have suggested that culturally Chinese people are sensitive to social context in their behavior. It follows that for this sample it is reasonable to find that certainty with interpersonal traits is more beneficial than certainty with personality traits. As Chinese culture can be characterized as interdependent, this tendency can also be explained with cross-cultural psychology research on independent and interdependent selfconstrual. For example, on the predictors of subjective well-being, Kitayama, Markus, and Kurokawa (2000) found that the reported frequency of general positive emotions (calm, elated) had a stronger relation with the reported frequency of interpersonally engaged positive emotions (friendly feelings) for Japanese students, but a stronger relation with the reported frequency of interpersonally disengaged positive emotions (pride) for American students. In addition, several studies have reported that variables subjected to the typical constructs of an independent culture, such as selfesteem, freedom, and self-consistency, have higher correlations with subjective well-being for Western people than for Eastern people (e.g, Diener \& Diener, 1995; Oishi, Diener, Lucas, \& Suh, 1999; Suh, 2002). Kwan, Bond, and Singelis (1997) found that relationship harmony had a stronger relation with subjective well-being than self-esteem among Hong Kong students, but not among American students. These findings on interdependent and independent self-construal revealed that people with interdependent self-construal are sensitive to the interdependent context, which means that constructs related to the interdependent context have greater influence on subjective well-being. Thus, the finding that certainty with interpersonal traits has more benefit than certainty with personality traits in predicting QOL is reasonable for the current sample.

\section{Implications for self research and adjustment}

Our findings may imply that the beneficial effect of self-certainty is rooted in the role-specific context because context-specific self-certainty can enhance the confidence to use self-knowledge when facing external situations. Although this finding is not unexpected, it points to an important perspective that has been neglected by past research on selfconcept pluralism and adjustment. In other words, our findings can extend self-certainty research to the issue of adjustment, and can also provide insight into self-concept pluralism research.

It has been theorized that individuals with high self-concept pluralism possess numerous specialized identities, enabling them to respond flexibly to the requirements of different social roles and hence demonstrate better adjustment (Gergen, 1971). However, many empirical studies do not support this argument (e.g., Bigler et al., 2001; Campbell et al., 2003; Donahue, Robins, Roberts, \& John, 1993; Rafaeli-Mor \& Steinberg, 2002). These studies did not incorporate self-certainty into their studies, which might explain the gap between theoretical perspective and empirical findings. These empirical studies usually conducted correlation analyses to investigate the relationship between measures of self-concept pluralism and subjective well-being. However, this procedure failed to explain how self-concept pluralism could lead to a better life. Self-concept pluralism enables response to requirements in different social roles. In fact, it is the ability to make a suitable response to different situations with appropriate self-aspects instead of pluralism itself that contributes to flexible and efficient adaptation in various situations. Only when one knows oneself can one retrieve appropriate selfknowledge corresponding to external requirements, or have the confidence in oneself to handle a situation and hence lead a better life.

It is also a possibility that high self-certainty represents a seeking of consistency rather than a flexibility in responding. As indicated in the introduction, people with high self-certainty use their self-knowledge to choose personal-fit situations and avoid risky situations. That is, selfcertainty allows people to seek situations that are compatible with themselves. This idea, referred to as self-verification theory, contends that a stable self-view provides people with a crucial source of coherence; people need to seek confirmation of 
their self-concept (Swann, Rentfrow, \& Guinn, 2002). With this motivation, people create social environments that reinforce their self-view and develop perceptions that are compatible with their self-view (Swann et al., 2002). For example, Pelham (1991) proposed that self-certainty stabilizes self-experience and makes individuals strive to resolve inconsistent experiences. In Pelham's fourth study, the stability of participants' most and least certain self-views was assessed in two distinct ways - absolute stability and correlational stability. Absolute stability was assessed by examining absolute changes in a person's self-view over a 10 -week period. Correlational stability was assessed by examining test-retest correlations for the self-view over the same 10 -week period. His results revealed that certainty of attributes contributes to both absolute stability and correlational stability. Moreover, other studies of selfverification theory have revealed that people with high self-certainty reinterpret self-inconsistent feedback to be more consistent (Swann \& Read, 1981), and actively resist others' attempts to change their self-view (Swann \& Ely, 1984; Swann, Pelham, \& Chidester, 1988). Accordingly, Pelham (1991) indicated that "high levels of belief certainty should insulate people from a number of sources of self-concept change" (p. 519).

Thus, from the perspective of responding flexibly and seeking consistency, self-certainty may play important roles in personal adjustment with two different functions. However, this twofunction perspective raises a further question as to the difference between control and self-certainty. That is, both response flexibility and consistency seeking can be regarded as a function of control, but at different stages. Response flexibility is control of the performing self in various situations and consistency seeking is control in choosing situations proactively. In this study, we only assessed the sense of control in general, and did not separate the two distinct meanings of control. In the future, this issue can be investigated with other research concerning the self, such as selfpluralism and self-verification.

\section{Limitations and future research}

Several limitations of this study should be addressed. First, the samples were restricted to National Taiwan University students. Although it is expected that our results can be generalized to other samples, cross-validation is needed. In addition, although we did cite related references to support our contention that high self-certainty people exercise control through situation selection, such as Setterlund and Niedenthal's report (1993) and Trope and Ben-Yair's study (1982), we did not include a behaviour indicator to strengthen our hypothesis. Although Setterlund and Niedenthal and Trope and Ben-Yair did show that people with high self-certainty display their tendency for control in choosing situations with personal fit, they did not incorporate adjustment measures or behaviour indicators to show that this personal-fit selection tendency has a positive benefit to adjustment. Thus, in a future study it would be worth incorporating these research approaches to construct a complete picture of the implications of self-certainty for adjustment.

Finally, in this study, self-certainty was only measured with a self-report method. This method cannot detect the accuracy of participants' selfperceptions and self-confidence. However, it can be argued that perception accuracy is not an important factor for self-certainty, because people with higher self-certainty have better adjustment, no matter whether their self-perception is accurate or not. Of course, perception accuracy may have an impact on the broad concept of adjustment. That is, when personal adjustment measures are used to define adjustment, it might not make a difference whether high self-certainty people have accurate self-perception or not, because both have the same confidence level and the same sense of control. However, when adjustment is defined from a person and environment interaction perspective, people with high self-certainty and accurate self-perception would be different in their adjustment in terms of the whole environment from those with inaccurate self-perception. People with high self-certainty and an accurate selfperception may choose the appropriate environment for themselves and fit the environment well, while people with high self-certainty but inaccurate self-perception cannot choose the appropriate environment and may experience conflict with others in that environment. Neglect of the role of self-perception accuracy is a limitation of this research. The positive relationship between selfcertainty and QOL cannot be used directly to conclude that people with high self-certainty have better adjustment if adjustment is viewed from a broad range. In a future study, observers' ratings for an individual's traits can be included as a criterion to check the accuracy of self-perception for an individual. The accuracy level could then be incorporated into the calculation of self-certainty. In addition, individuals' adjustment with respect to their environment can also be evaluated from an observers' perspective. It may be expected that 
people with high self-certainty and accurate versus inaccurate self-perception would not differ in personal adjustment measures, but would differ in social environmental adjustment measures as evaluated by observers.

In sum, this research shows that people with more self-certainty had a stronger sense of control, and hence led a better life. However, many aspects can be further examined in detail to gain a complete picture.

\section{Manuscript received December 2005 Revised manuscript accepted October 2006}

\section{REFERENCES}

Baumgardner, A. H. (1990). To know oneself is to like oneself: Self-certainty and self-affect. Journal of Personality and Social Psychology, 58, 1062-1072.

Bentler, P. M. (1990). Comparative fit indexes in structural models. Psychological Bulletin, 107, 238-246.

Bigler, M., Neimeyer, G. J., \& Brown, E. (2001). The divided self revisited: Effects of self-concept clarity and self-concept differentiation on psychological adjustment. Journal of Social and Clinical Psychology, 20, 396-415.

Bowlby, J. (1969). Attachment and loss, Vol. 1: Attachment. New York: Basic Books.

Browne, M. W., \& Cudeck, R. (1993). Alternative ways of assessing model fit. In K. A. Bollen \& J. S. Long (Eds.), Testing structural equation models. Beverly Hills, CA: Sage.

Campbell, J. D. (1990). Self-esteem and certainty of the self-concept. Journal of Personality and Social Psychology, 56, 538-549.

Campbell, J. D., Assanand, S., \& Di Paula, A. (2003). The structure of the self-concept and its relation to psychological adjustment. Journal of Personality, 71, 115.

Campbell, J. D., Trapnell, P., Heine, S. J., Katz, I. M., Lavallee, L. F., \& Lehman, D. R. (1996). Selfconcept clarity: Measurement, personality correlates, and cultural boundaries. Journal of Personality and Social Psychology, 70, 141-156.

Carver, C. S., \& Scheier, M. F. (1998). On the selfregulation of behavior. New York: Cambridge University Press.

Cooley, C. H. (1902). Human nature and the social order. New York: Scribner's.

Diener, E., \& Diener, M. (1995). Cross-cultural correlates of life satisfaction and self-esteem. Journal of Personality and Social Psychology, 68, 653-663.

Donahue, E. M., Robins, R. W., Roberts, B. W., \& John, O. P. (1993). The divided self: Concurrent and longitudinal effects of psychological adjustment and social roles on self-concept differentiation. Journal of Personality and Social Psychology, 64, 834-846.

Gergen, K. J. (1971). The concept of self. New York: Holt.

Hoyle, R. H. (1995). The structural equation modeling approach: Basic concepts and fundamental issues. In R. H. Hoyle (Ed.), Structural equation modeling: Concepts, issues, and applications (pp.1-15). Thousand Oaks: Sage.
Hu, L., \& Bentler, P. M. (1999). Cutoff criteria for fit indexes in covariance structure analysis: Conventional criteria versus new alternatives. Structural Equation Modeling, 6, 1-55.

Hwang, K. K. (2000). Chinese relationalism: Theoretical construction and methodological considerations. Journal for the Theory of Social Behavior, 30, 155-178.

Joreskog, K. G., \& Sorbom, D. (1993). LISREL 8: Structural equation modeling with the SIMPLIS command language. Hillsdale, NJ: Lawrence Erlbaum Associates Inc.

Kitayama, S., Markus, H. R., \& Kurokawa, M. (2000). Culture, emotion, and well-being: Good feelings in Japan and the United States. Cognition \& Emotion, 14, 93-124.

Kwan, V. S. Y., Bond, M. H., \& Singelis, T. M. (1997). Pancultural explanations for life satisfaction: Adding relationship harmony to self-esteem. Journal of Personality and Social Psychology, 73, 1038-1051.

Lachman, M. E., \& Weaver, S. L. (1998). The sense of control as a moderator of social class differences in health and well-being. Journal of Personality and Social Psychology, 74, 763-773.

Langer, E. J., \& Rodin, J. (1976). The effects of choice and enhanced personal responsibility for the aged: A field experiment in an institutional setting. Journal of Personality and Social Psychology, 34, 191-198.

Lefcourt, H. M. (1991). Locus of control. In J. P. Robinson, P. R. Shaver, \& L. S. Wrightsman (Eds.), Measures of personality and social psychological attitudes. San Diego, CA: Academic Press.

Lucas, R. E., Diener, E., \& Suh, E. (1996). Discriminant validity of well-being measures. Journal of Personality and Social Psychology, 71, 616-628.

Mead, G. H. (1934). Mind, self, and society. Chicago: University of Chicago Press.

Oishi, S., Diener, E., Lucas, R. E., \& Suh, E. M. (1999). Cultural variation in predictors of life satisfaction: A perspective from needs and values. Personality and Social Psychology Bulletin, 25, 980-990.

Paulhus, D. L., \& Van Selst, M. (1990). The Spheres of Control scale: Ten years of research. Personality and Individual Differences, 11, 1029-1036.

Pelham, B. W. (1991). On confidence and consequence: The certainty and importance of self-knowledge. Journal of Personality and Social Psychology, 60, 518-530.

Rafaeli-Mor, E., \& Steinberg, J. (2002). Self-complexity and well-being: A research synthesis. Personality and Social Psychology Review, 6, 31-58.

Rodin, J. (1986). Aging and health: Effects of the sense of control. Science, 233, 1271-1276.

Rodin, J., \& Langer, E. J. (1977). Long-term effects of a control-relevant intervention among the institutionalized aged. Journal of Personality and Social Psychology, 35, 275-282.

Rodin, J., Timko, C., \& Harris, S. (1985). The construct of control: Biological and psychosocial correlates. Annual Review of Gerontology and Geriatrics, 5, 3-55.

Schulz, R. (1976). Effects of control and predictability on the physical and psychological well-being of the institutionalized aged. Journal of Personality and Social Psychology, 33, 563-573.

Schulz, R., \& Hanusa, B. H. (1978). Long-term effects of control and predictability-enhancing interventions: 
Findings and ethical issues. Journal of Personality and Social Psychology, 36, 1202-1212.

Seeman, M., \& Seeman, T. E. (1983). Health behavior and personal autonomy: A longitudinal study of the sense of control in illness. Journal of Health and Social Behavior, 24, 144-160.

Setterlund, M. B., \& Niedenthal, P. M. (1993). "Who am I? Why am I here?': Self-esteem, self-clarity, and prototype-matching. Journal of Personality and Social Psychology, 4, 769-780.

Skevington, S. M., Lotfy, M., \& O'Connell, K. (2004). The World Health Organization's WHOQOL-BREF quality of life assessment: Psychometric properties and results of the international field trial. A report from the WHOQOL group. Quality of Life Research, 13, 299-310.

Spittal, M. J., Siegert, R. J., McClure, J. L., \& Walkey, F. H. (2001). The Spheres of Control Scale: The identification of a clear, replicable threefactor structure. Personality and Individual Differences, 32, 121-131.

Suh, E. M. (2002). Culture, identity consistency, and. subjective well-being. Journal of Personality \& Social Psychology, 83, 1378-1391.

Sullivan, H. S. (1953). The interpersonal theory of psychiatry. New York: Norton.

Swann, W. B., \& Ely, R. J. (1984). A battle of wills: Selfverification versus behavioral confirmation. Journal of Personality and Social Psychology, 47, 1287-1302.

Swann, W. B., Pelham, B. W., \& Chidester, T. R. (1988). Change through paradox: Using self-verification to alter beliefs. Journal of Personality and Social Psychology, 54, 268-273.

Swann, W. B., \& Read, S. J. (1981). Self-verification processes: How we sustain our self-conceptions. Journal of Experimental Social Psychology, 17, $351-372$.
Swann, W. B., Rentfrow, P. J., \& Guinn, J. (2002). Selfverification: The search for coherence. In M. Leary \& J. Tagney (Eds.), Handbook of self and identity. New York: Guilford Press.

Trope, Y., \& Ben-Yair, E. (1982). Task construction and persistence as a means for self-assessment of abilities. Journal of Personality and Social Psychology, 42, 637-645.

Wardle, J., Steptoe, A., Guliš, G., Sartory, G., Sek, H., Todorova, I., Vögele, C., \& Zairko, M. (2004). Depression, perceived control, and life satisfaction in university students from central-Eastern and Western Europe. International Journal of Behavioral Medicine, $11,27-36$.

Wiggins, J. S. (1979). A psychological taxonomy of trait-descriptive terms: The interpersonal domain. Journal of Personality and Social Psychology, 37, 395-412.

World Health Organization. (1993). WHOQOL study protocol (MNH/PSF/93.9), Geneva, Switzerland: WHO.

World Health Organization. (1995). Resources for new WHOQOL centers (MNH/PSF/95.3), Geneva, Switzerland: WHO.

Yang, K. S. (2004). A theoretical and empirical analysis of the Chinese self from the perspective of social and individual orientation [in Chinese]. Indigenous Psychological Research, 22, 11-80.

Yang, C. H., \& Kao, H. S. R. (Eds.) (1991). Chung-kuo jen Chung-kuo hsin [in Chinese]. Taipei, Taiwan: Yuan-Liou.

Yao, G., Chung, C. W., Yu, C. F., \& Wang, J. D. (2002). Development and verification of reliability and validity of the WHOQOL-BREF Taiwan Version. Journal of the Formosan Medical Association, 101, 342-351. 